\title{
Railway Water Towers in Szolnok
}

\author{
Architecture \\ Zsuzsanna Gábor-Szabó \\ 40/2 (2009) 65, 75 \\ doi: 10.3311/pp.ar.2009-2.03 \\ web: http://www.pp.bme.hu/ar \\ (c) Periodica Polytechnica 2009 \\ RESEARCH ARTICLE \\ Received 2010-02-18
}

\begin{abstract}
The industrial water towers built by the railway companies at the end of the 19th century predated the first generation of municipal public supply towers in most towns of Hungary.

This paper focuses on the town of Szolnok, the principal station on the Pest-Szolnok railway line. As the third railway track of the country, it was opened to public steam locomotive transportation in 1847. It was a water station where the locomotives' tanks were refilled with water from an elevated reservoir.

Although in a ramshackle state, one of Szolnok's railway water towers still remains, awaiting a well-deserved renovation. This listed industrial monument bears an Intze Type I tank of which only a few have survived in the country. A photodocumentation presents a newly discovered, Intze Type II railway tower the vicissitudes of which are also traced through written documents. By the demolition of this latter one in the middle of the 20th century the era of historicism in the architecture of railway buildings has come to an end. New utilitarian railway water tower types of reinforced concrete were created throughout the country, an example of which was also constructed in Szolnok.
\end{abstract}

\section{Keywords}

water tower $\cdot$ Intze $\cdot$ railway $\cdot$ architecture $\cdot$ industrial architecture

\section{Zsuzsanna Gábor-Szabó}

Budapest University of Technology and Economics Department of History of Architecture and of Monuments, H-1111 Budapest, Múegyetem rkp. 3. K. 260., Hungary

e-mail: zsuzsi@ viztorony.hu

webpage: www.viztorony.hu

\section{The history of the Szolnok railway stations}

Ten years after the committee decisions in the Parliament of Pozsony (today Bratislava, Slovak Rep.) in 1836, the first Railway Act $\left(\mathrm{N}^{o} \mathrm{XXV}\right)$ was declared designating the thirteen most important railway tracks to be established in Hungary [7, p. 34]. The Hungarian Central Railway Company undertook among others the Pest-Debrecen line whose first section to be built was that between Pest and Szolnok. Situated on the northern bank of the River Tisza one hundred kilometres to the East from Pest, the town of Szolnok was an important centre of trade and an ideal junction point of waterways and overland transportation. Its key role in the traffic of the territory East of the River Tisza provided good reasons for being the recipient of this new mode of vehicle transport in order to "transform it into the basis of improvement for national commerce" - as it was claimed by István Széchenyi [3. p. 12] , one of the first passengers arriving at Szolnok by train.

The first railway station of Szolnok was designed by the Viennese Wilhelm Paul Edward Sprenger and built by Mátyás Zitterbarth and was worthy of Széchenyi's wish. Near the river bank the still existing reception hall of this station witnessed the arrival of the first locomotive on $1^{\text {st }}$ September $184 \lambda^{1}$. The ÓSzolnok station (as the oldest station building of Hungary $2^{2}$ is now called) served as the passenger station only for a decade since the railway track branching off towards Debrecen in 1857 avoided the town further to the North in order not to cut the city off from its river bank [5, p. 122].

At the new site a Romantic style reception hall with central and side bays was built over one year according to the standard design of the Tiszavidéki Railways Company in 1857. The former station with its engine shed and water house (Fig. 1) contin-

\footnotetext{
${ }^{1}$ According to most scholarly publications, after the Pest-Vác railway track (33 km) inaugurated on $15^{\text {th }}$ July 1846 , the Pest-Cegléd-Szolnok line $(99 \mathrm{~km})$ started to operate as the second public steam operated railway in Hungary. This widely spread statement can be regarded to be true only, if we consider the lines constructed by the Hungarian Central Railway Company exclusively, but actually the opening of the $27 \mathrm{~km}$ long Sopron-Lajtaszentmiklós rail line (achieved by the Sopron-Bécsújhely Railway Company) predated that of the Pest-Szolnok line by 12 days, since it was opened to the public on $20^{\text {th }}$ Aug. 1847 [6 p. 11]. $2[13$ p. 317]
} 


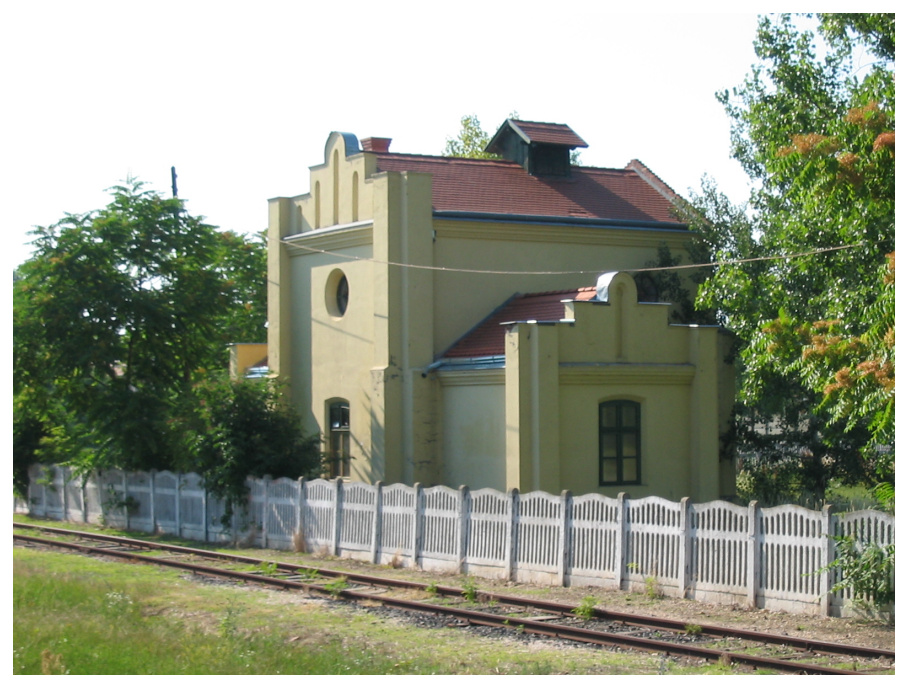

Fig. 1. The water house of the Ó-Szolnok station, built ca. 1850 was renovated for the $150^{\text {th }}$ anniversary of the inauguration of the Pest-Szolnok line.

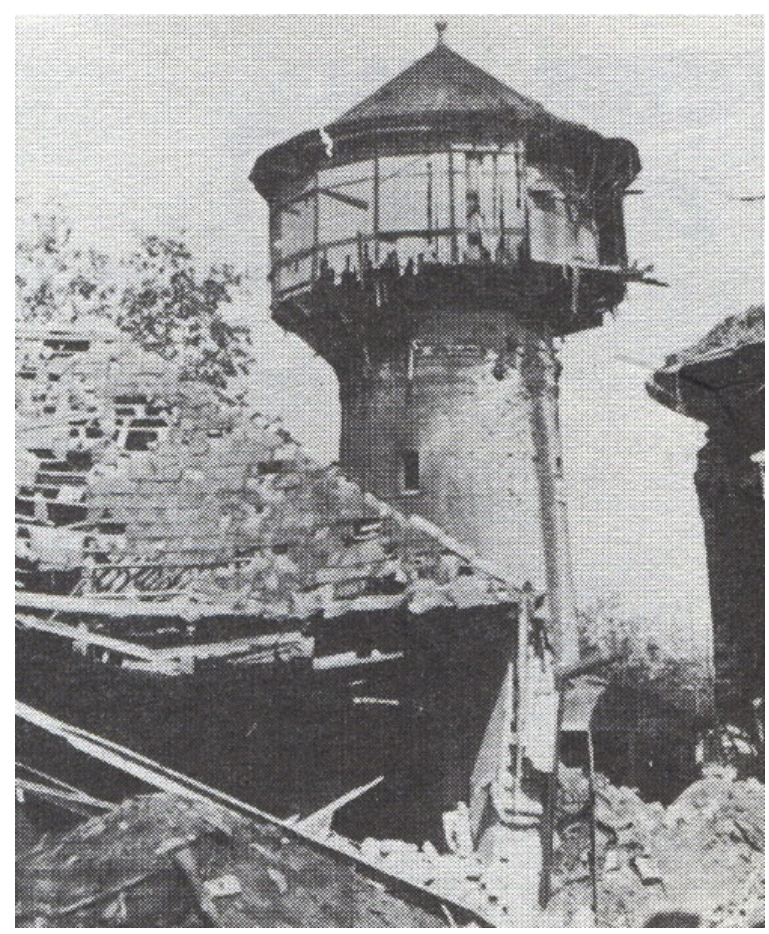

Fig. 2. Bomb hit station water tower in the summer of 1944 (b. 1910).

ued managing the heavy traffic; presumably the construction of the water house took place in the 1850s. The task of this small, one-storey building to the South-West of the reception hall was the water supply for the locomotives and the storage of water. It had three parts: a well beneath its ground floor level, a pump on the ground floor and a water tank on the first floor. It had a rectangular shaped plan with two symmetrical side wings [13, p. 319].

During the first decade of use the railway vehicles didn't require a large maintenance base because the locomotives, carriages and wagons were brand new and only six trains ran on this line [11, p. 17].

As the traffic increased, the Tiszavidéki Railway Company started to set up a repair workshop for the vehicles in an area, which was at equal distance from both stations. The still exist- ing Vehicle Repair Enterprise, which is still one of Szolnok's significant factories was founded in 1856. Little is known of its first buildings before 1880, when following nationalisation, most of the buildings were modernized and rebuilt on the site.

Around the turn of the century Szolnok became a remarkable railway junction point. During half a century the passenger traffic had increased to such an extent that the construction of a third reception hall was needed. The constructor of this building was the Hungarian State Railway Enterprise (MÁV). Its specific architectural design came from Ferenc Pfaff, who turned away from his own conventional style for this instance. What he created was a well-proportioned elongated building with plastered facades on which the window and door frames were accentuated with red-brick rims; the corners, friezes and mouldings were outlined with similar wall bandings. Although it was one of the most outstanding railway reception halls of the country, it could not escape its destiny. Sadly 37 years after its inauguration in 1907, it was completely destroyed by the saturation bombing carried out by the Anglo-Saxon airforce. The harm done to the buildings of the station on the $2^{\text {nd }}$ June 1944 was so devastating that the station was hardly serviceable [5] p. 122].

As for the parallel history of the Vehicle Repair Enterprise, it was a great success: in the period between 1894-1929 several engine repair workshops were erected and the company became one of the fifteen most important independent head-workshops of the country. Sprenger's station buildings were still in use when on the company's elongated plot besides the rails leading to the Ó-Szolnok station, the water supply system of the engine-repair halls was erected in 1900. A service water tower completed the system "which had a cylindrical brick wall, and a riveted iron tank with timber sheathing. It's capacity was 120 cubic meters" [11, p. 20]. An intensifier pump was also installed in the tower which was necessary later on during the expansion of the pipe network due to the enlargement of the company's territory [8, p. 41]. In the historical résumé published on the occasion of the centenary of the company, a detailed report gives a vivid description of how the German troops demobilized the destroyed engine halls and plundered the machinery remains which had survived the saturation bombing of 1944. In the text another water tower is also mentioned, the physical traces of which cannot be found on the actual railway area of the town. The author says that "the workmen staying on the site have successfully prevented the Germans from blasting the service and the station water towers, together with the agricultural warehouses" [8, p. 82].

There is hardly any written evidence to be found either in the municipality's nor in the national railway archives about the aforementioned water tower of the station. In the private photo collection of Csaba Virágh, accessible via the homepage of the Hungarian water tower 3 a picture (Fig. 2) depicts this tower in

\footnotetext{
3 tttp://www.viztorony.hu/h/jasz-nagykun-szolnok/szolnok/ Q7.html (accessed at 20/06/2009)
} 
its miserable bomb-torn state right after the air raid. The lack of information available about this sizeable tower inspired the first phase of this research. Later, the pieces of information collected little by little and presented in the following sections lead to the conclusion that both towers were of a special type, namely Intze-towers after the inventor's name, who patented the riveted iron tank forms enclosed in numerous railway water towers built around the turn of the $20^{\text {th }}$ century in Western Europe.

The basis of my assumptions are the standard plans of "Incze (sic!)" water towers designed for the Hungarian Royal State Railway Company found in the MÁV Archives. There are three of them: two with a deceptively similar appearance 4 with a $120 \mathrm{~m}^{3}$ capacity Intze Type I tank. These plans can only be distinguished by two details: the date of issue indicated in the bottom right corner of the sheet and the heights of the towers' cylindrical brick shafts; the taller tower's shaft reaches 16 meters from the ground, and it was issued on $24^{\text {th }}$ January 1899 . On the smaller one, dated $26^{\text {th }}$ April 1898, the shaft height is only $14 \mathrm{~m}$. Considering the measurements of the shaft of the still existing water tower of the Vehicle Repair Enterprise (completed in 1900), it is evident that the plan dating from 1898 was realized in Szolnok (Fig. 3). The third standard plan presents an Intze Type II tank with the capacity of $500 \mathrm{~m}^{3}$ (Fig. 4). The short handwritten notes on the plan do not indicate a place or date, neither if such a tower has ever been built or not. But this can be inferred from the characteristic features of the whole body of the tower and also from a document issued in 1910 and claiming that "a $500 \mathrm{~m}^{3}$ tank must be built for Szombathely taking the existing water tower in Szabadka and those to be built in Szolnok and Érsekújvár as an example.'5 This means that the station tower in question was approximately coeval with the reception hall designed by Pfaff.

The inscriptions on the plans indicate that the design is about a certain Intze patent. It appears that the person's name is incorrectly spelt as "Incze" but undoubtedly it refers to Otto Intze's patents.

\section{The Intze Patent and its predecessors}

In Western Europe the steam drawn trains became more and more dominant in the management of overland traffic and transportation. The economical operation of the fully steam driven line connecting Liverpool and Manchester opened in Britain in 1830 had convinced the leaders of other countries on the continent that instead of the horse drawn railed traffic the steam engine powered locomotives were bound to succeed in the future. The railway lines established throughout Europe increasingly required the construction of the economically executable and maintainable elevated water tanks.

Since the steam cycle of the locomotives is a typically open process - i.e. the used steam is continuously vented to the atmosphere - water must be supplied from time to time. The water

\footnotetext{
${ }^{4}$ Central Archives of MÁV document PHML fond no. 6179, plan no. 944a.

${ }^{5}$ Central Archives of MÁV document no. 17792/1912 (MÁV Szombathely)
}

utilization of the locomotive depended on several factors from which the relative distances of water supplying stations were calculated according to different methods. These factors were: the type of the locomotive, its general condition, the velocity and train loading, the relief of the track and the speed limits as well as the weather conditions and the quality of the water loaded [9. p. 20].

The stopping points enabling the refilling of the locomotives' tenders with water were called water stations. Their distribution along the railway lines were elaborated taking the most unfavourable water consumption into account. This meant that besides the traction plants - where the boiler cleaning and reloading happened parallel to water refilling - each 30 to $50 \mathrm{~km}$ long railway section had their own water station where next to the lines a pump and reservoir tank was put into service and connected to a natural water source or to the municipal waterworks.

Almost all kinds of water producing procedures were applied in order to provide water for the water stations. Water was elevated by various methods from the artesian or deep bore wells: man-power, steam engines, petrol engines, electromotor as well as by ejectors or pulsometers that were operated by the steam of the locomotive being refilled [12, pp. 96-97]. To be more costeffective, on the Great Hungarian Plain the Tiszavidéki Railway Company also operated some wind-motor powered reciprocating or centrifugal pumps ${ }^{6}$ The sails of the windmill could either be mounted on a free-standing steel structure or directly onto the roof top of the water tower ${ }^{7}$ In case of small, rarely-frequented water substations, there was no need for an elevated tank, but the water source was in direct connection with the pipes leading to the water crane from which the tender of the locomotive was filled. Stations with a considerable amount of traffic however were generally equipped with an elevated water reservoir in order to facilitate rapid refilling.

The structure of these tanks and their supporting construction depended on the capacity they were designed for. In the second half of the $19^{\text {th }}$ century and at the beginning of the $20^{\text {th }}$ century, cylindrical shaped riveted iron tanks were the most widespread. Up to a volume of $40 \mathrm{~m}^{3}$, the tanks often had flat floor bolted together with vertical wall panels and could be square or rectangle shaped in plan. Unless the flat base was made uneconomically thick, they needed to be supported on a grid or raft of beams erected upon a massive brick or masonry wall [4, p. 149]. After a patent of the French engineer, Jules Dupuit (1804-1866) in 1855 , tanks with a capacity exceeding $60 \mathrm{~m}^{3}$ were designed with a convex or dome-shaped floor. These so called dished based tanks could be erected on more economical supporting structures since an iron ring-beam carried their weight and transmitted it to the cylindrical shaft. The precise fastening of this ring beam to the bottom-wall joint of the tank often caused problems and therefore the tank became unstable during filling and dis-

\footnotetext{
$6 \longdiv { 1 0 }$ pp. 474-475] describes the free-standing wind-motor at the railways station of Kisújszállás.

7 [12. 100], Fig. 64.
} 


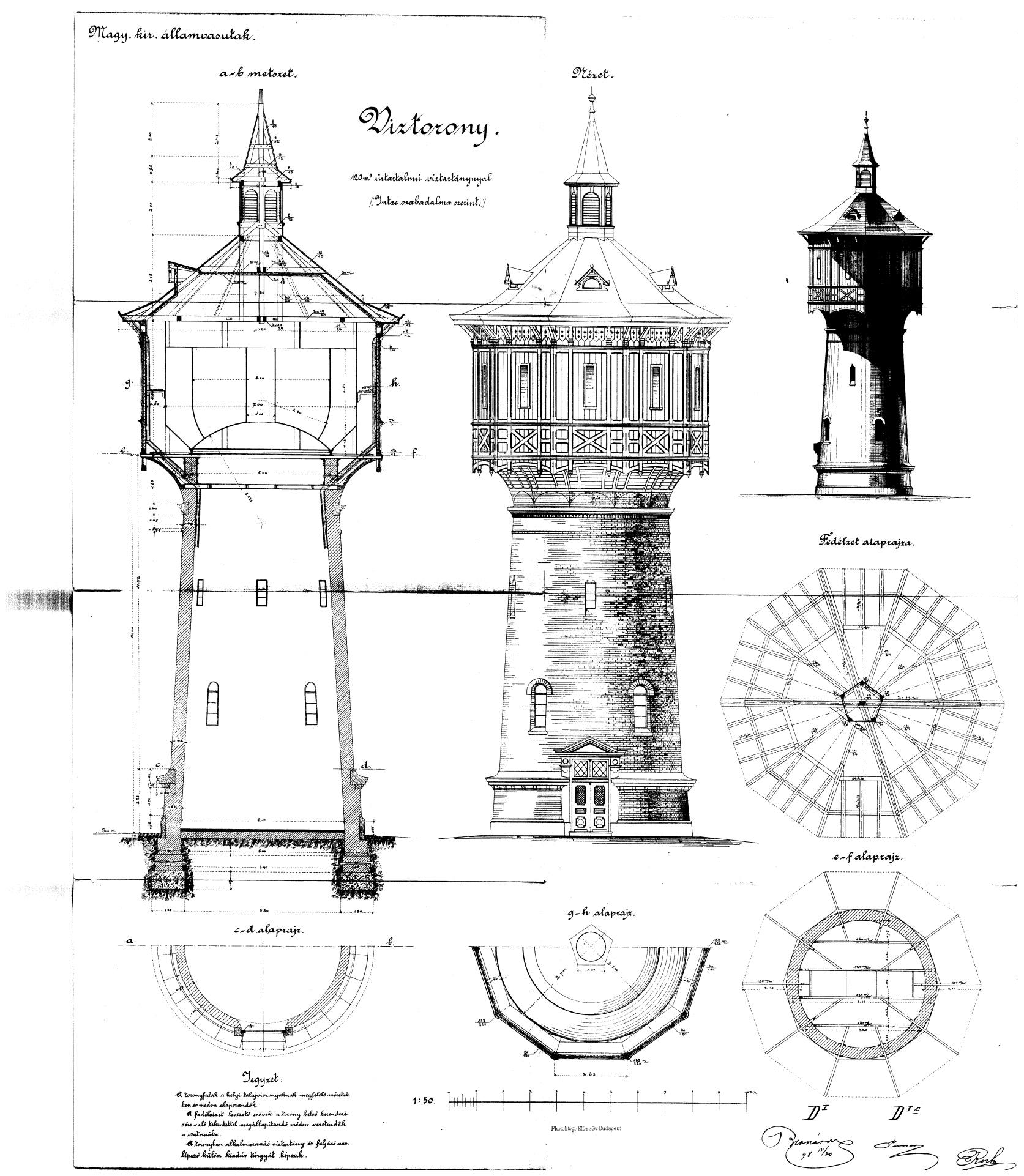

Fig. 3. Standard plan of $120 \mathrm{~m}^{3}$ Intze Type I water tower, 1898.

charging.

To eliminate this problem the German Professor Otto Intze (1843-1904), of the Technische Hochschule at Aachen, intending to improve Dupuit's dished based tanks started to elaborate a circular tank bottom the central portion of which consisted of an inverted shallow dome and the outer part an inverted, truncated cone. The cone and the dome converged on a ringbeam, the diameter of which was thus less than that of the cylindrical riveted iron tank which topped this floor shape. The dimensions of this compound tank shape were carefully calculated to ensure that the outward forces at the base of the dome balanced the inward forces at the base of the truncated cone, consequently the resultant force on the ring beam was oriented vertically downwards (Fig. 5). As for the ringbeam, it could be relatively modest in size and about two thirds the diameter of the tank, which resulted in a relatively slender supporting structure that enabled a $20-25 \%$ reduction of the building costs.

The first water tower enclosing an Intze-type iron tank was constructed in 1883 in Remscheid (Germany). It had a capacity of $400 \mathrm{~m}^{3}$. Owing to its advantageous power play from 15 to 

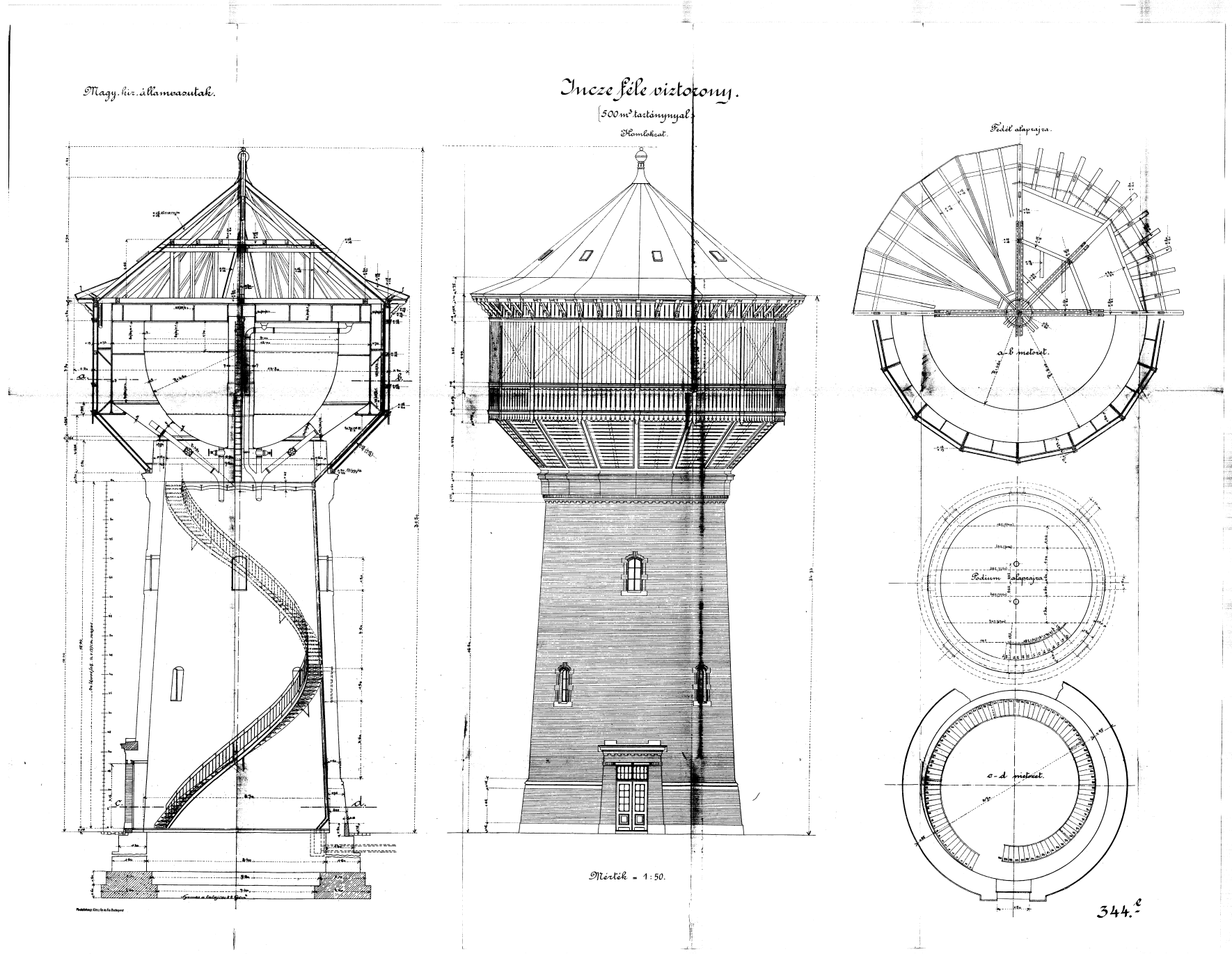

Fig. 4. Standard plan of $500 \mathrm{~m}^{3}$ Intze Type II water tower, ca. 1910.

$1000 \mathrm{~m}^{3}$ capacities, tanks with Intze's design started to spread along the European railway lines. The fact that we make a distinction between an Intze Type I and Type II is because over a tank volume of $500 \mathrm{~m}^{3}$, the waste space under the inverted dome was so large that it was worth turning the central part of the tank's floor into a dished base again (Fig. 6). The new design kept Intze's initial invention of reducing the horizontal forces to a minimum on the ringbeam. On the rim of the dished base a second ringbeam was needed, but normal-size angle irons were sufficient for this. The construction of Type II was less complicated and the danger of buckling was practically eliminated.

The special outlook of an Intze-type tank encased in a tower comes from its corbelled head which was covered with timber decoration and a roof top against frost ${ }^{8}$ This facade architecture peculiar to Romanticism was intended to blend in with the style of the railway buildings designed around the turn of the $20^{\text {th }}$ century throughout Europe.

\footnotetext{
${ }^{8}$ Generally if the water in the tank was regularly pumped in winter, the air between the wall of the iron tank and its timber or masonry covering served as a satisfactory heat insulation against the danger of freezing.
}

\section{The Intze-type water reservoirs of Hungary}

In order to evaluate the importance of the Szolnok railway towers and their justified rank in the country's industrial building heritage, research was launched to locate the Intze railway tanks with regards to their type distinction inside the present day borders of Hungary. In the railway archives there are hardly any exact data to be found about the railway water towers, even less about the Intze-type ones. But there are some towers still visible today.

In Budapest, the establishment of the steam engine repair workshops began in 1902 in the territory of the Istvánteleki Principal Workshop. Its foundation was motivated by the rapid increase of railway traffic and the Western Workshop (operating from 1846 on the territory of the Western Railways Station) had to be relieved of the locomotive repair works.

In Istvántelek, two water towers were built, both with an Intze Type I tank with a capacity of $120 \mathrm{~m}^{3}$ (Fig. 7). The degradation of these towers began in the 1980s when the operation of steam traction locomotives finally ended in Hungary. Unfortunately these towers fall outside the interests of national heritage protection although they are undoubtedly unique examples of railway 


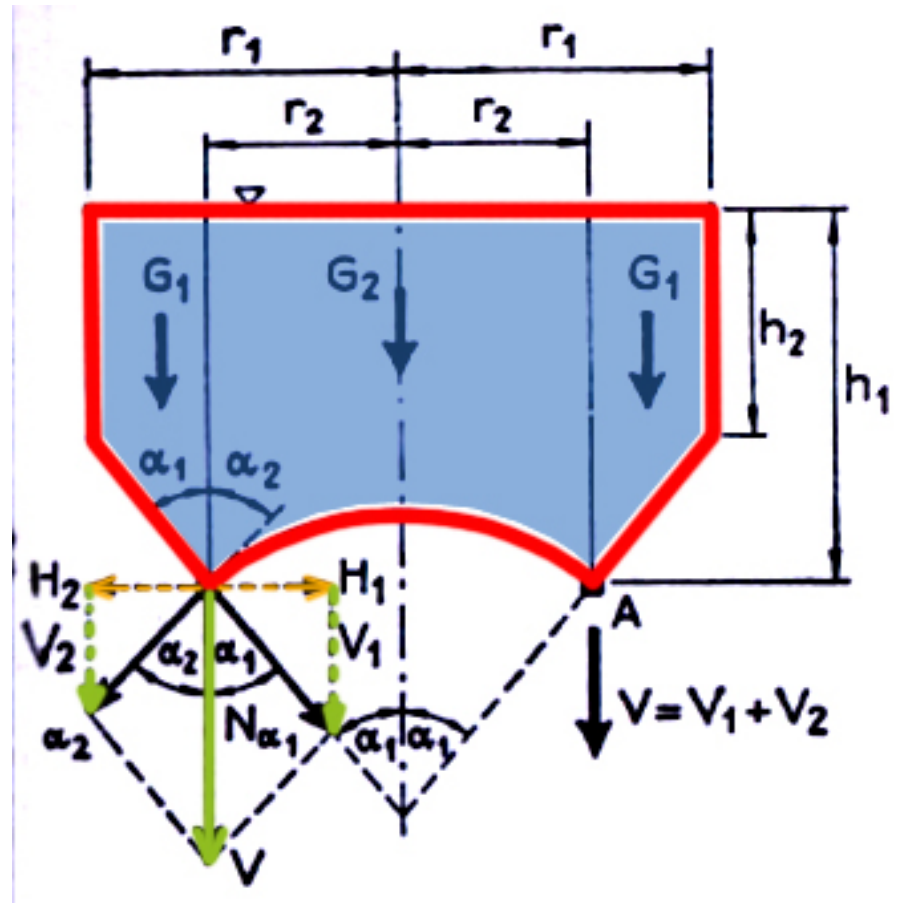

Fig. 5. The statics of an Intze Type I tank, showing the resolution of forces.
A

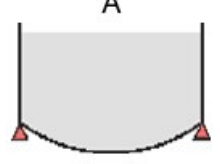

B

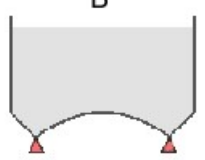

C

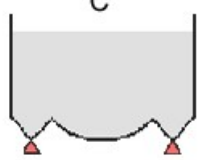

Fig. 6. Structural comparison of the dome-bottom tanks. A: Dupuit's tank, B: Intze Type I tank, C: Intze Type II tank

tower design. The patent of Intze refers solely to the form of the iron tank encased in them not to the stairwell or pipework equipment. By virtue of these original solutions both towers could be applicants for protection even if they are a couple of years younger than the Intze Type I tower in Szolnok.

In order to facilitate the settlement of its workers in Budapest the Hungarian Royal State Railways started to establish worker's estates on the outskirts of the capital at the end of the $19^{\text {th }}$ century. Practically these estates had direct connections to the railway lines or stations just like the one in Ferencváros (Budapest) along Gyáli út. On this estate mostly one-storey terraced houses were built with four flats in a block according to the standard plans of MÁV. Later on, at the beginning of the 1930's, threestorey blocks of flats also started to be built on the site. In order to ensure the water supply of the inhabitants with an appropriate water pressure a "railside" water tower was built in the centre of the estate. Its Intze Type I tank had an almost cylindrical timber revetment just as the aforementioned towers. The quality and the fine details of the eaves supports, the coupled rectangular aperture frames on the side sheathing with subtle timber string-courses gave it an elegant character blending in with the nearby terraced houses. This consciously formed, well proportioned tower still stands out amongst the roofs of the estate,

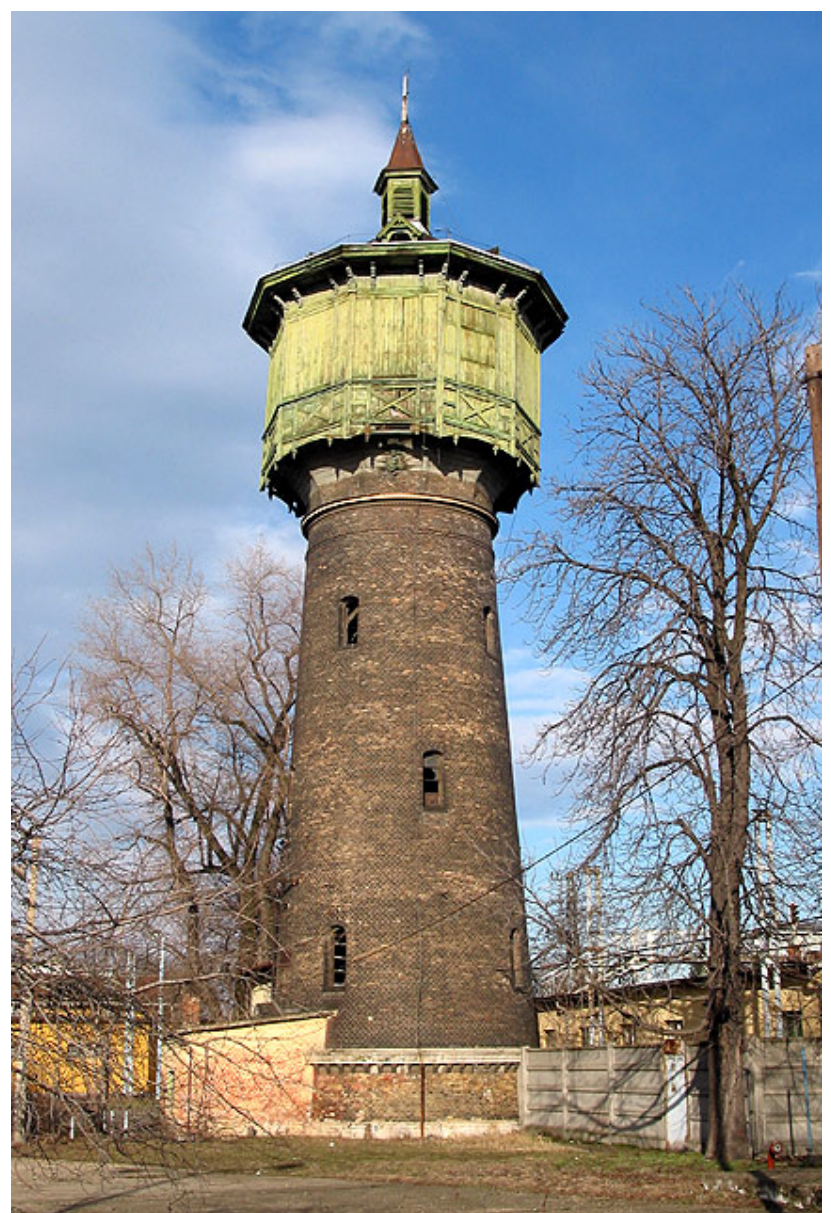

Fig. 7. Southern water tower of the Istvánteleki Principal Workshop, b. 1902 .

though in a much transformed state. In 1987 the tower (at that time no longer in use) was in such a miserable condition that it was threatened by demolition initiated by MÁV as the proprietor. The national heritage authority did not agree with the removal of this peculiar landmark of the townscape of Pest. Finally with the municipality's financial support a private investor bought and converted the tower into his own luxury flat. By every means the tower has survived and received a new character which respected the original details to a great extent, although the traces of its original function have been lost forever (Fig. 87.

The list of Intze Type I water towers can be completed with three imposing edifices although not belonging to the examples of railway architecture and also contrasting with them in the aspect of the materials used to form their facades. The Óbuda Gas Factory established between 1910-13, had a remarkable group of industrial towers which were used in the processing of gaswater tar mixture. Among the four towers the tallest one with the four clocks on its upper part had a $750 \mathrm{~m}^{3}$ capacity Intze Type I tank containing industrial water. In addition, it also contained three additional cylindrical cast iron tanks in its shaft, one above each other. Despite of the tower's fine majolica ornamentation, sculptured ledges and striped brick wall with a red and light brown render in its present dilapidated state it presents a poor example of a listed industrial monument (Fig. 9). 


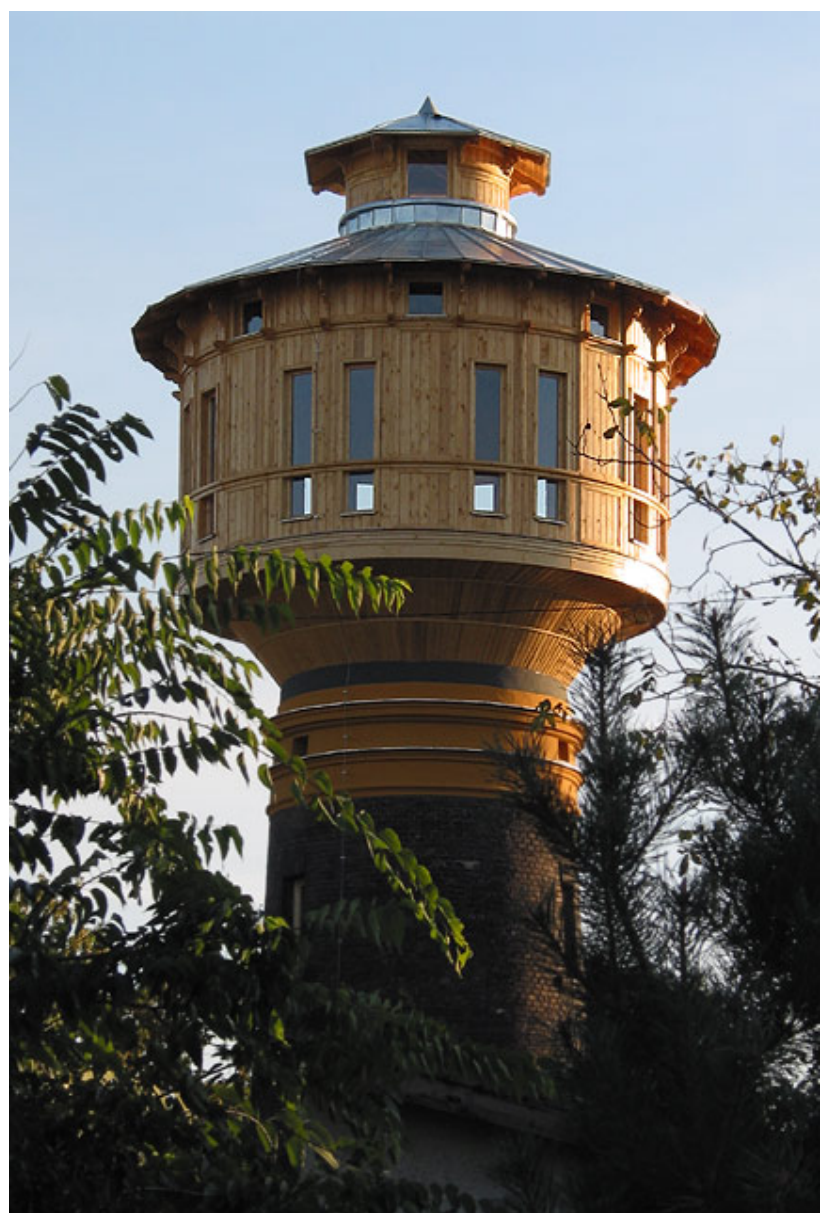

Fig. 8. Reused water tower of Gyáli út, 2005.

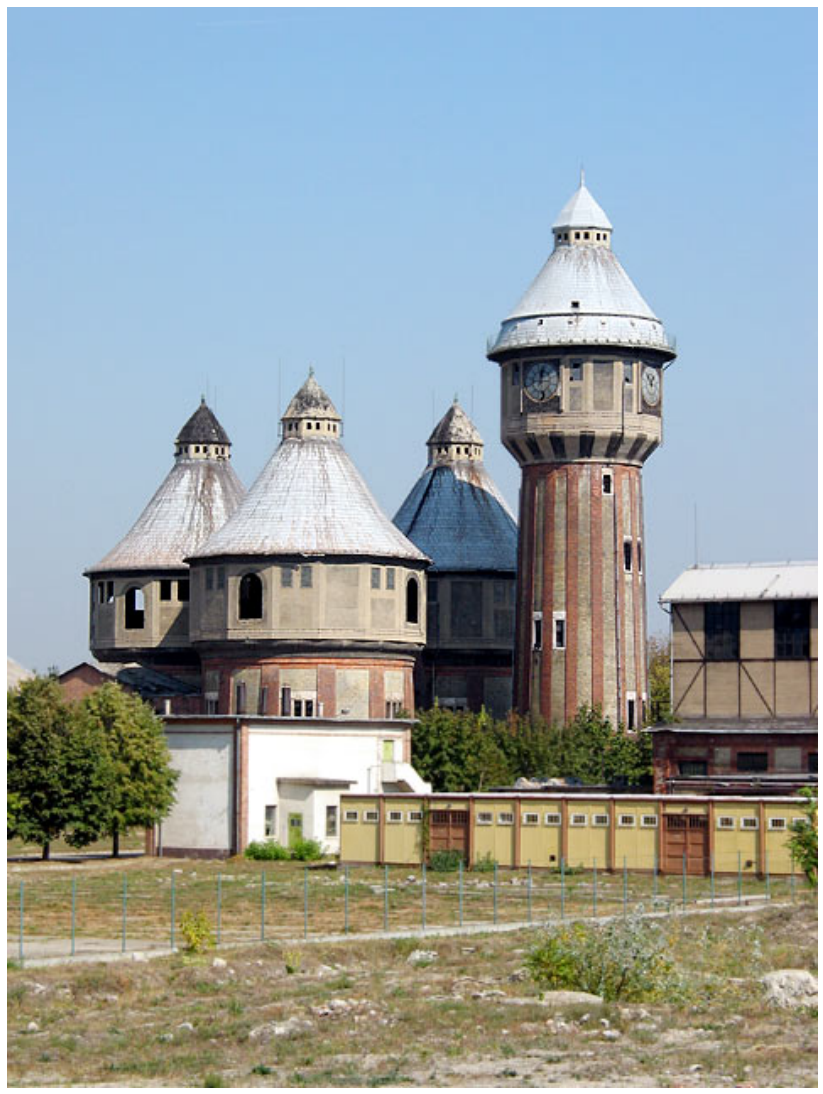

Fig. 9. Tar towers and the water tower of the Óbuda Gas Factory b. ca.1913.
The Árpád út municipal water supply tower in Újpest $\left(4^{t h}\right.$ district of Budapest) bears the largest Intze Type I riveted iron tank ever built in Hungary (Fig. 10). In 1912 its designers Ödön Dümmerling and Győző Mihailich planed the construction of a $1500 \mathrm{~m}^{3}$ capacity tank with the diameter of $15 \mathrm{~m}$ and the highest water level of $40 \mathrm{~m}$ above the level of the road. On the top of its sizeable brick shaft there are eight reinforced concrete brackets anchored by horizontal bars supporting the concrete wall surrounding the tank and the Schwedler-type octagonal, steelstructure cupola [1, pp. 60-61]. It played an important role in the industrial water supply of the $4^{\text {th }}$ district of Budapest until 2003. Then it was emptied and became a listed industrial monument without any prospect of reuse.

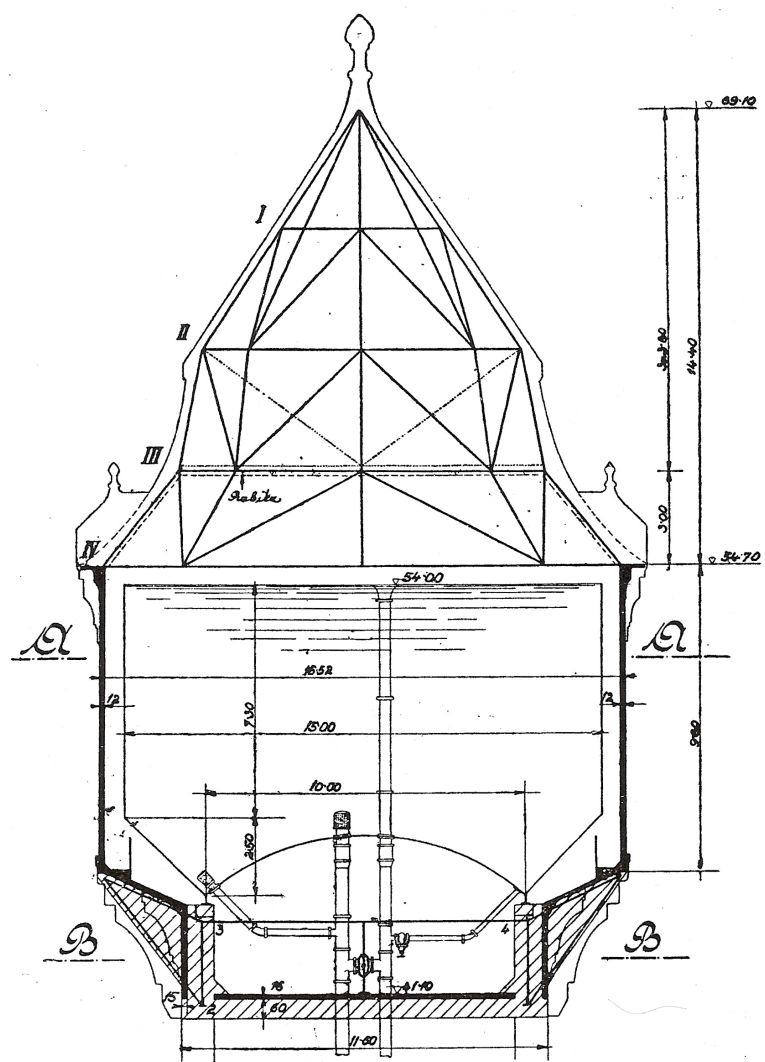

Fig. 10. Section of the head of the water tower on Árpád út, Budapest (b. 1912) after Magyar Mérnök és Építész Egylet Közlönye. 1913/8. p. 137.

The third water tower that should be mentioned in this section differs from all the already presented ones. It is the reinforced concrete tower on Margaret Island in Budapest with a water tank of $600 \mathrm{~m}^{3}$ (Fig. 11). It is the form of its tank, which connects it to the towers discussed here. In 1912, Szilárd Zielinski and Rezsô Ray extended Intze's principle to the new building material of the $20^{t h}$ century. The distinctive shape of the tank can be recognized in the corbelling of the upper part of the tower erected on a ring of columns. This is the characteristic sloping base of the outer cone which is hence made visible. The inner dome which required a complex shuttering serves as the cupola over the accessible balcony level under the tank. 


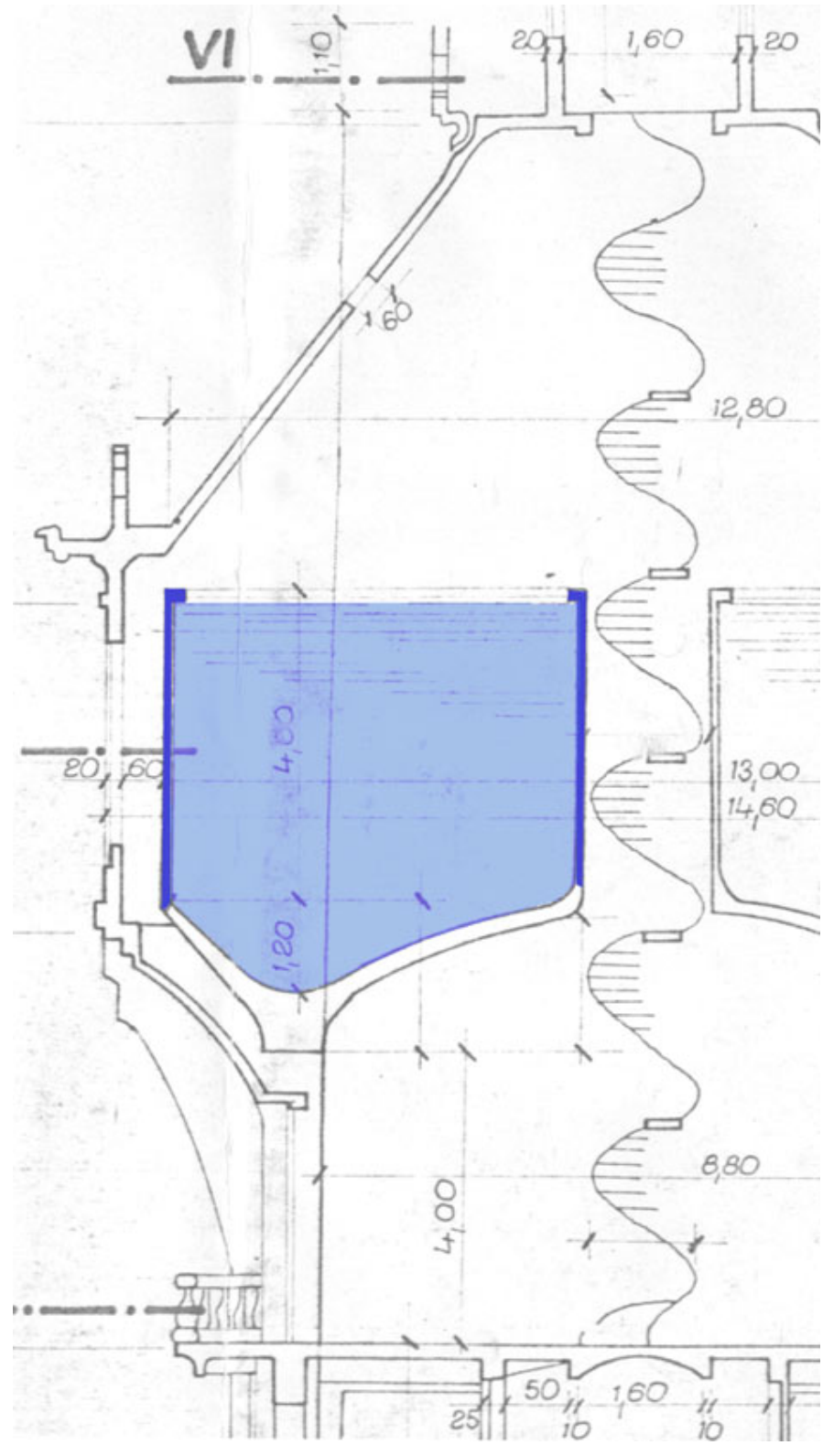

Fig. 11. Partial section of the water tower on Margaret Island (b. 1912) showing the form of its reinforced concrete tank. Courtesy of FVM Rt. Archives.

In contrast to the relative abundance of Type I, there are hardly any examples of the second larger type of Intze reservoirs to be found in present day Hungary. But the fact that the Hungarian Royal State Railways actually adopted the standard plan of the Intze Type II tank is shown by the water tower on Tatai út in Budapest (Fig. 12). The territory where this huge tank of $1000 \mathrm{~m}^{3}$ capacity supported by a massive circular brick shaft was erected, belonged to the Northern Principal Workshop founded in 1867. Starting from the 1890 s - as its name suggests - this workshop was charged with the maintenance and repair of the locomotives coming from the Eastern regions of Hungary like Pozsony (Bratislava) and Érsekújvár (Nové Zámky, Slovak Rep.). The $59 \mathrm{~m}$ high, gambrel roofed tower was built in 1911. Its twin-compartment tank had a ten-sided timberstructured covering which can not be seen any more. The tower was discharged at the beginning of the 1980s and the timber cov- ering was pulled down together with its imposing roof structure. Since then the tank has been exposed to the eroding factors of the weather. Only photographs recall its original state for old time's sake.

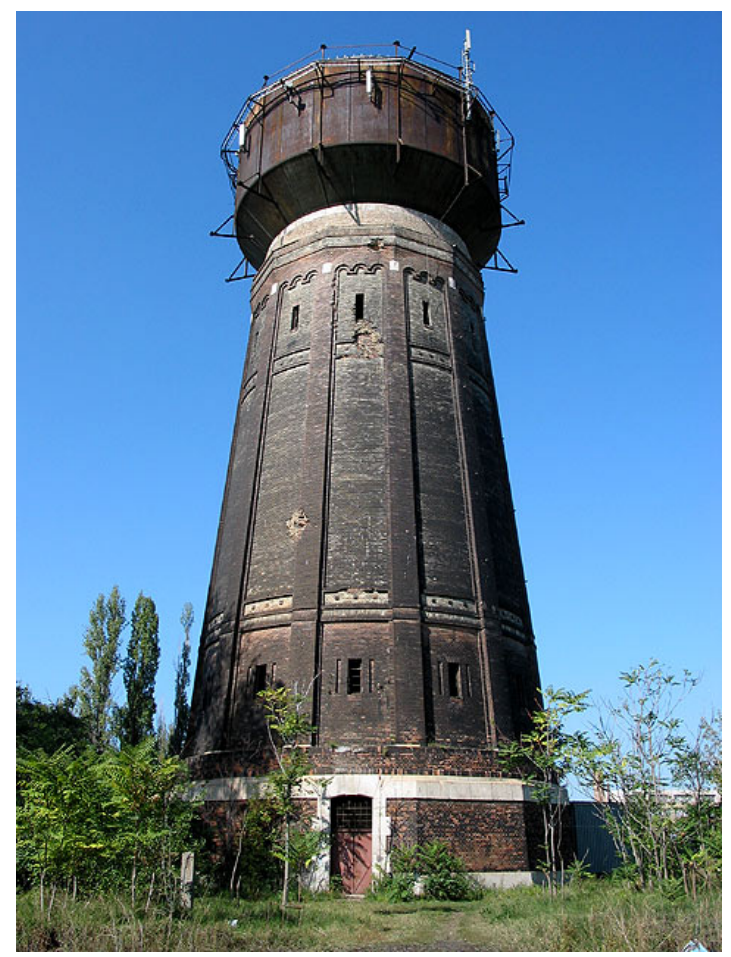

Fig. 12. Water tower of the Northern Principal Workshop, on Tatai út, b.1911.

\section{The Intze Type I water tower in Szolnok}

Considering the examples of Intze Type I tanks in a chronological order we can conclude that with its construction in 1900 the still existing listed water tower of the Vehicle Repair Enterprise in Szolnok is the earliest one (Fig. 13). Having recognized this fact the author initiated its survey in 2008 [2, pp. 13-19].

The truncated cone shaped brick shaft of the tower is covered with clinker which has a brownish yellow render. On its inner surface there is a whitewashed thin plaster. At ground level the diameter of the shaft is $5.95 \mathrm{~m}$, the thickness of the basement circular wall is approximately $58 \mathrm{~cm}$. The floor is made of concrete. Due to there being no surviving plan, the depth and the dimensions of the foundation cannot be ascertained.

Inside the shaft, steep steel-structured stairs connect the three platforms of diminishing sizes above each other. The top floor which closes down the shaft is made of steel plates fastened on a grid of steel beams. Its lower level is $14.90 \mathrm{~m}$ above ground level. In the axis of the shaft three intact pipes ascend towards the tank. These are the inlet, supply outlet and overflow pipes the sections of which are connected to each other by riveted rims. Through a trapdoor a steep steel ladder provides access to the space below the tank which is covered by the inverted dome of the tank's floor. The supply pipe bifurcates and obliquely joins at two points to the bottom of the tank. This arrangement suggests that the tank has two compartments which was a prac- 


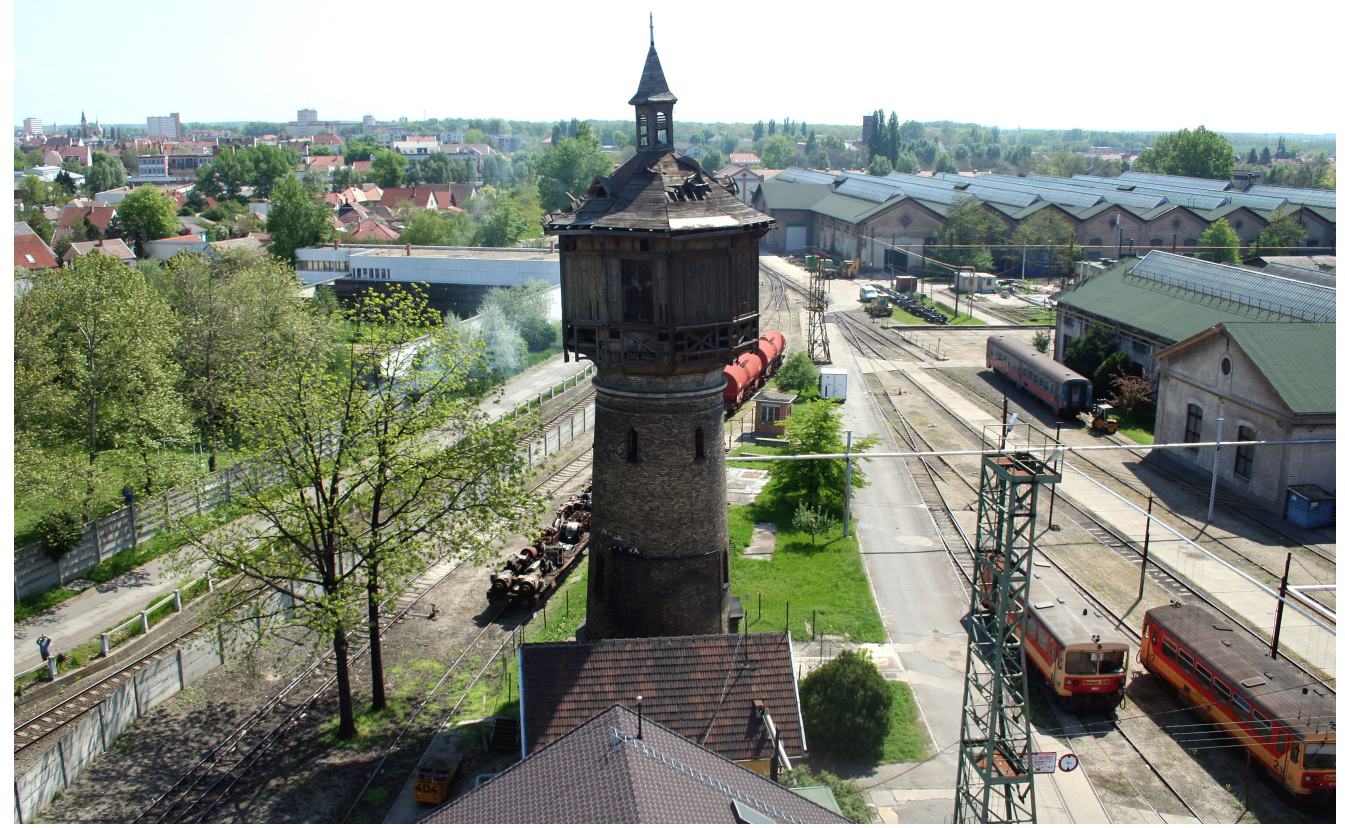

Fig. 13. Service water tower on the territory of the Vehicle Repair Enterprise in Szolnok, b. 1900.

tical and hence widespread solution to enable the maintenance and regular cleaning including the removing of the warp and repainting. A circular iron wall divides the tank into two cylindrically symmetric sections with a ring shaped plan.

The access into the tank and towards the roof is through a narrow central core inside the tank. The diameter of this access shaft is nearly $1.00 \mathrm{~m}$ but half of its area is already occupied by a steel ladder and the inlet and overflow pipes which have two junctions to the two sections respectively. The circular timber roof structure and the ten-sided side boards of the covering decoration are fastened to a supporting steel structure which is composed of ten short cantilevers made of steel beams built into the highest wall section of the shaft just under the tank. By the side of two of these cantilevers, gutters break through the wall directing the precipitation collected from the eaves towards the ground floor through the interior of the shaft. The inefficiency of this internal gutter has resulted in the wetting of the tower's foundation.

The top level of the brick shaft and the upper horizontal beam of the surrounding cantilevers are on the same level to which the Y-shaped tank-supporting ringbeam is fastened. The V-shaped riveted ring joint of the tank's floor fits into it.

Due to the poor state of the tower no additional data could be observed on site about the space between the tank's wall and the dilapidated timber cover around it. The cause of this degradation is the failing tin-plate covering of the roof. The photodocumentation taken from the air showed traces of five little triangular scuttles equidistant from each other around the central pentagonal louvre.

As for the description of the centrally symmetrical facade of the tower, it has a few fine details worthy of mentioning. The base of the tower is surrounded by a moulded hard limestone plinth up to the height of 35 to 50 centimetres. A ring ledge of the same type of stone with the total height of $52 \mathrm{~cm}$ supported by 54 pieces of truss ornates the shaft at $1.50 \mathrm{~m}$ height. The sharpest element of the facade is the entrance. Two carved limestone pilasters frame the door which is topped with a pediment. Above the panelled wooden doorwings there is a barred transom window which was once fitted with glass.

Around the shaft of the tower, ten windows with stone ledges are equally arranged. Four equidistant arched windows with the dimension of $65 \times 165 \mathrm{~cm}$ are at the level of the second floor. In the window on the right side of the entrance an iron stovepipe strikes out from the interior. It belongs to the still existing steam boiler which was used to power the pumps settled on the ground floor of the tower. The third level of the shaft is lit with six windows with the dimension of $45 \times 105 \mathrm{~cm}$. The upper part of them is decorated with a simple triangular shaped staggered brick ornament. On the top of the shaft there is a simplified tripartite cornice made of clinker and limestone.

The ten-sided double boarding of the timber structure surrounding the tank is made of trimmed pine strips. The lower edge of each side is cambered and a 'HXH-shaped' ornament is fixed on it made from templates. To the endings of the vertical pieces of the timber frames small-sized lathe-turned elements are joined as a decoration. The central part of each sideboard has a rectangular false window frame. Under the eaves, barely though, the carved knee-timber pieces can still be recognized.

The author has the strong hope that the tower's upcoming renovation will stop its degradation and that it becomes an appreciated edifice of our national industrial heritage from the era of locomotives.

\section{The Intze Type II water tower in Szolnok}

Having found the first traces of the station's water tower, the research continued in the Photoarchives of MÁV. The exact po- 
sition and the history of this tower after 1944 was in question. With the help of the negatives, an interesting story took shape. The earliest photo was taken in 1940 on the occasion of the construction of a nearby flyover bridge. The shaft of the tower is totally hidden on this picture 9 but the form of the upper timberclad part and the cone-shaped roof can be recognized. The most important element of this picture which is common with the detail shown in Fig. 2 is the rectangular lath grid over the plain timber boards. The picture taken in 1944 also shows the horizontal cracking of the brick shaft (Fig. 2).

Four years passed until the next pictures that were taken on $28^{t h}$ October 1948. On this series of pictures the final phase of the scaffolding of the new reinforced concrete tower's starshaped shaft is presented (Fig. 14). Incidentally two of them show the tower in question as well. It stands approximately 20 $\mathrm{m}$ apart from the ongoing construction. With these photos the conclusion can be made that after the bombing, the tower was restored and kept on supplying the re-established railway traffic. In order to strengthen its damaged shaft seven pieces of strained steel strips were fastened around it at equal distances. These strips cross both rows of the small windows breaching the shaft. The timber structure also appears renovated, since the lath grid has totally disappeared. The proof of the fact that the restoration was not totally satisfactory is the splayed large pole which seems to be an auxiliary support of the tank fixed into the ground.

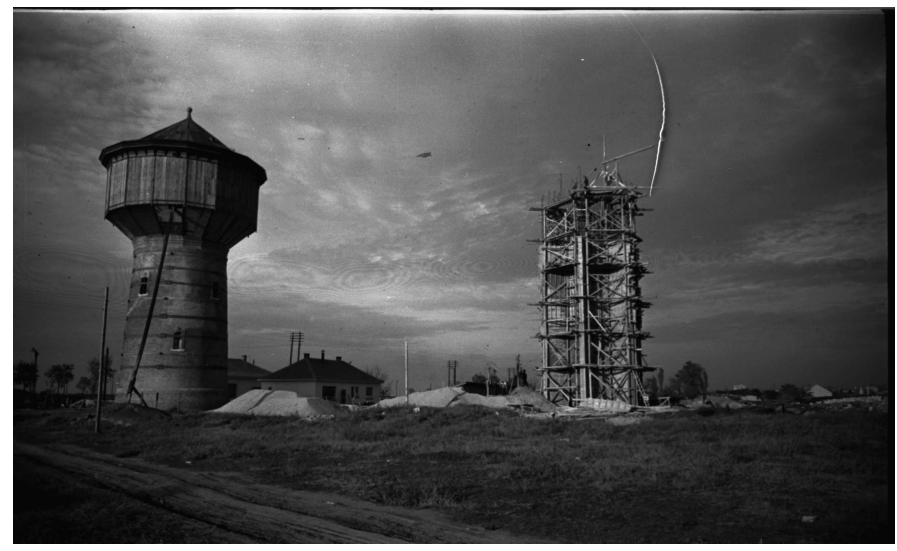

Fig. 14. Station water tower in 1948 near the building site of the new tower. Courtesy of MÁV Archives.

The position from where the pictures were taken on $29^{\text {th }}$ June 1949 enable the precise positioning of the tower with respect to the still existing new tower and the flyover bridge which is in the background of the picture. A photo taken in 1952 (Fig. 15) shows the tower alone by the railway lines of the station and some other pictures taken in the same year prove that by that time the new water tower was totally finished (Fig. 17). The question of how long the two towers were standing side by side cannot be definitely answered. No information of the date of demolition of the old tower has yet been found. Since it is missing from the general plan of the construction of the actual Modern

\footnotetext{
$\sqrt[9]{3}$ figure without no. following p. 64.
}

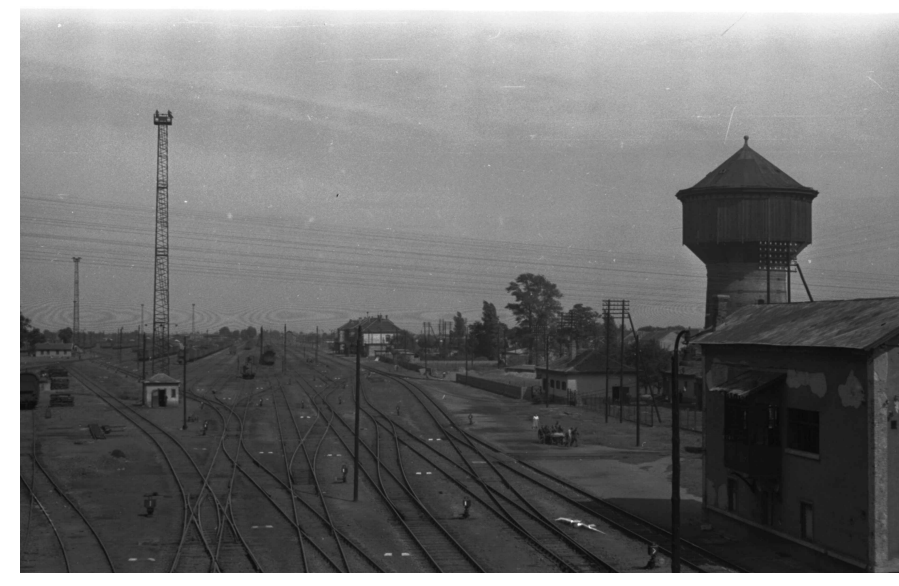

Fig. 15. Position of the station water tower related to the station and the flybridge, 1952. Courtesy of MÁV Archives.

Style railway station buildings, it can be concluded that by 1967 it has already ceased to exist.

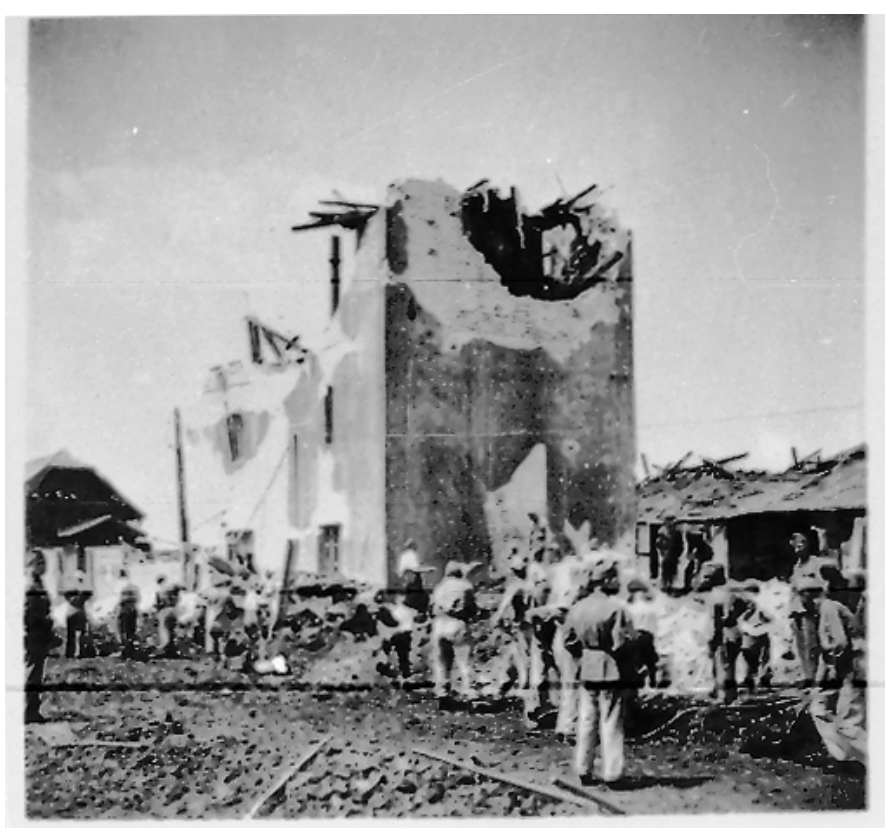

Fig. 16. Bomb hit older station water tower in the summer of 1944, (b. ca. 1850). Courtesy of the Municipal Archives in Szolnok.

By the study of the standard plan of an Intze Type II tower created around 1910 we can assume that unlike the tower on Tatai út, the one in Szolnok was designed in accordance with it. Hence the identity of the inner structures of it can be presumed as well.

As a result of this research the history of the railway buildings in Szolnok is enriched. There is one more water tower which has not vanished without a trace as the water cranes of the station have in the last fifty years.

\section{Water houses and new railway water tower types}

There are two more water towers that must be mentioned to complete the series of towers in connection with the railways in Szolnok. 
In the period between 1857 and 1910 the passenger station built by the Tiszavidéki Railways Co. must have had its own water supply independent of the Ó-Szolnok goods-station. A document about the technical inspection of both stations in 1874 lists the buildings of the passenger station and among them there is the "building of the water station" [14, p. 65]. Recently a photograph has been uncovered in an exhibition commemorating the $65^{\text {th }}$ anniversary of the saturation bombing of Szolnok which showed a rectangular water house with its fully destroyed upper floor (Fig. 16). A brownish coloured cylindrical tank and its pipes can be seen on it. From the dimensions of the building two such tanks can be estimated as on site, next to each other which was a characteristic arrangement of the end of the $19^{\text {th }}$ century. Presumably this was the main water supplying tank before the Intze Type II tank was built.

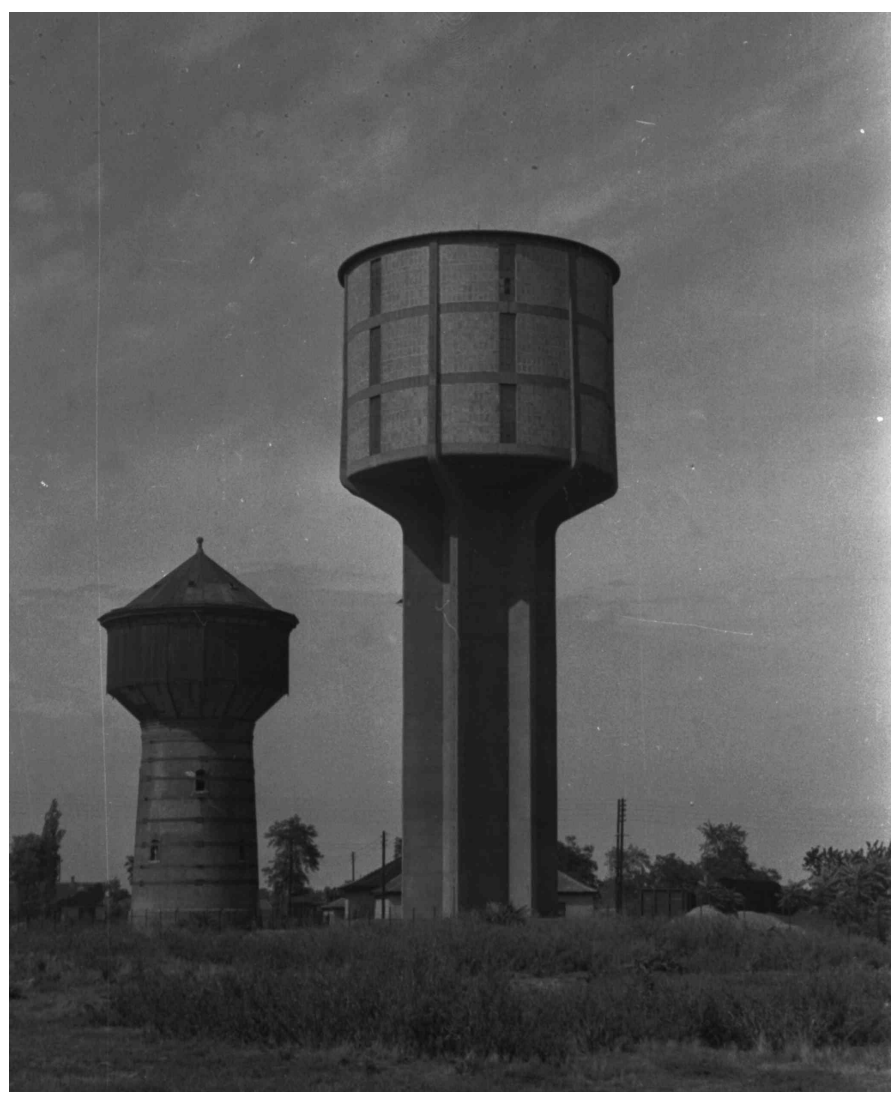

Fig. 17. Old and new water towers together at the Szolnok Railways Station, 1952. Courtesy of MÁV Archives.

Nearly a century later, a new railway water tower of $1000 \mathrm{~m}^{3}$ capacity was built of reinforced concrete according to the new standard plans used by the MÁV. This tower has been mentioned above as standing next to its predecessor (Fig. 17). This cylindrical type along with others with a smaller capacity were built at numerous Hungarian stations in the 1950s and 1960s. The materials, forms, structures and architectural details of them compared to those of their predecessors demonstrate the development of all-time architectural theory in the sense of industrial building design.

\section{References}

1 Bertók L, Füstös A, Gábor-Szabó Zs, Lánczi A, Solymosi K, Víztornyok Magyarországon, Magyar Víziközmú Szövetség, Budapest, 2007.

2 Gábor-Szabó Zs, Mérôszalag, légifotó, térszkenner-Esettanulmány a szolnoki múemlék víztorony felméréséról, BME Mûemlékvédelmi szakmérnöki képzés, 2008. Szakdolgozat.

3 Kaposvári Gy, Szolnok közlekedéstörténete, Szolnok megyei Lapkiadó Vállalat, Szolnok, 1976.

4 Komjagin L F, A vasút vízellátása, Közlekedési Kiadó, Budapest, 1953.

5 Kubinszky M, Gombár Gy, Vasútállomások Magyarországon - Épületek 1846-1988, Népszava Kiadó Vállalat, Budapest, 1989.

6 Mezei I (ed.), Vasúthistória Évkönyv, MÁV Rt. Vezérigazgatóság, 1997.

7 Mezei I, Somody Á, Fejezetek a 150 éves magyar vasút történetéból, MÁV Rt., Budapest, 1996.

8 Molnár S, 100 év a MÁV Szolnoki Jármújavító Ü. V. történetéból 1856-1956, Szolnok megyei Néplap Lapkiadó Vállalat, Szolnok, 1960.

9 Pápay I, Vasúti vízállomások teljesítóképessége, Vasúti Tudományos Kutató Intézet, 1952. Tanulmány.

10 Perner J, Hochbau, Geschichte der Eisenbahnen der OesterreichischUngarischen Monarchie (Strach H, ed.), Wien, Unknown Month 1898. 465475.

11 Simon B, Másfél évszázad: A MÁV Szolnoki Jármújavitó története - 18562006, Fotogruppe Kiadó Kft., Szolnok, 2006.

12 Steiner M, Vasúti vontatási szolgálat, Wodianer, Budapest, 1910.

13 Szikszai M, Régi vasúti épületek Szolnokon. Az indóházak története 18471909-ig, Jászkunság 47 (1997), 317-322.

14 _ Vasúti állomásépületek Szolnokon (1847-1975), Zounok 12 (1997), 39-85. 